WINCENTY KWIATKOWSKI

\title{
Beginnings and Development Of the Warsaw Apologetic School*
}

Sources and literature on the subject: W. Kwiatkowski, Subject of total apologetics, Warsaw 1937; Methods in Total Apologetics, Warsaw 1938; Modern Views on the Structure (Ontic and Intentional) of Religious Experience, "Polonia Sacra" 5 (1952), 224-237; Subject of Scientific Apologetics, "Collectanea Theologica" 30 (1959), 10-19; R. Paciorkowski, Internal Structure of Modern Apologetics, "Collectanea Theologica" (1954), 10-40; St. Nagy, Main Directions of Research in Contemporary Catholic Apologetics, "Theological and Canonical Yearbooks" 7 (1960), 119-136; W. Hładowski, Structure of Apologetics, "Theological and Canonical Yearbooks" 11 (1964), 33-53.

In the introduction to the above-mentioned topic, I would like to explain what I mean by the term "school" and "apologetic school" in the scientific sense. I use the term "school" in the scientific sense to refer to a team (a collection, a system, an arrangement) of sentences, critically tested, which includes an attempt to solve one of the main issues in a specific field of knowledge and acquires for itself numerous supporters and spreaders for a longer time. Therefore, by the term "school of apologetics" in the scientific sense I mean a team (a collection, a system, an arrangement) of critically verified sentences that provides us with an attempt to solve one of the main problems of apologetics and gains for itself numerous supporters and spreaders for a longer time until this attempt is replaced by another system of sentences. Such a major issue in modern apologetics, which was attempted by the Warsaw School of Apologetics, centered mainly on the team Chair of Apologetics. At the Faculty of Theology of the Catholic Academy of Theology, there is the question of the internal structure or internal organization of modern apologetics in one scientific system, as a field of knowledge 
already independent and separate from other closest to it, i.e. theology and religiosity. From the view of the development of the history of science, we know that every science is mature or independent and separate from others, when it has its own material and formal object. Moreover, the larger and closer the unity occurs in the material and formal object in a given field of knowledge, i.e. the greater the logical cohesion in the structure of the material and formal object, the greater its independence and distinctness marked among other sciences. Therefore, the question is whether since the mid-18 ${ }^{\text {th }}$ century the development of apologetics has already gone so far that we are now able to determine its separate material and formal object with the most advanced logical unity or cohesiveness to which it is entitled. The treaties de revelatione and de ecclesia, distinguished in theology in the mid- $18^{\text {th }}$ century, constituted in the apologetics at the time only a seemingly entire whole, alternatively an associative whole. 1. The implicative integration of a material object in contemporary apologetics. Having worked in the field of apologetic research for fifty years (1914-1964), I have witnessed not only great passive but also active transformations that took place in its material subject regarding transformations made in the auxiliary areas: religious and biblical.

Research into the history of religion that developed in the second half of the $19^{\text {th }}$ century and at the beginning of the $20^{\text {th }}$ century led researchers to a purely evolutionary assumption that Christianity is nothing more than the last level of natural human development in the field of religion. Such a radical-evolutionist approach, however, could not be carried out without violating the historical sources of the Christian religion. Therefore, a need arose to revise the existing comparative method in studies on the history of religions. This change was made by an outstanding religion. In 1929, professor Pinard de la Boullaye, an expert professor, published a two-volume work entitled L'etude comparee des religions, in which he established six principles (priority, organic unity, uniformity, dependence, originality and transcendence; recognized by the critics up to the present day) that should guide any critical comparative method in the history of religion. These principles (especially the fifth and sixth ones), far from a priori evolutionism, open up opportunities for religions that transcend the framework of any evolution. By enabling verification of the character of the original and relative transcendence of religion, this method has overturned the exaggerated position of religious evolutionism, according to which lower religious forms inherently lead to higher ones and vice versa, higher religious forms arise only from lower ones.

Another equally significant turn in religious research, especially in the field of religious psychology, has been triggered starting from the moment professor 
K. Girgensohn published his work Der Seelische Aufbau des religiósen Erlebens in 1921. After his death, the second edition, enlarged and supplemented, was published by his student W. Gruehn in 1930. Girgensohn's famous work, based solely on the experimental method used for religious experience, showed that its structure was not psychologically homogeneous as it had been until then in the rationalist and Protestant circles, which supported Luther's dogmatic stance on the act of faith as an act of trust. There was a return to a Catholic approach to an act of faith based on acts of reason and will (DBUR 1789). Girgensohn's experimental research has established beyond any doubt that a religious experience (act of faith) consists of an intellectual and self-function in terms of its psychological structure, with the intellectual function taking the leading role in the religious experience, and again feelings enter into this role as a resonance of the self-function. Girgensohn's momentous research has wiped out the previous position of biblical and philosophical rationalism, according to which Christian faith or the very experience of this faith is something exclusively emotional or irrational and subjective. From now on, every religious experience becomes an experience in which reason appears as a cognitive and guiding factor in relation to religious reality.

Furthermore, the above experimental research has shown a certain characteristic feature of a religious experience, namely that whoever is a religious believer and is aware of his or her religion or beliefs wants them to be true. This is because no-one wants to experience a false religion or a false world view. On this basis, apologies of different religions are created as a natural basis and apologetics as a science with critical value of these apologies is consistently created.

Breakthrough religious works of Pinard, Girgensohn and Gruehn have influenced the current approach to the material object in modern apologetics in the sense that it excludes from the scope of this object that which was a component part of what was known as the demonstratio religiosa, which was a substitute for religious research spreading extreme evolutionism and irrationality. It seems that the demontratio religiosa, which in the old construction of apologetics entered as the first part of a material object, loses all theoretical bases in apologetics, because it can and must be replaced by history and the psychology of religion, developed on critical bases. Then, Girgensohn's experimental studies showed that the material subject of apologetics should be, by nature, apologia of religion, and in our case, apologia of the Christian religion, the oldest and most classical, come from Jesus himself.

By limiting the scope of apologetics to the examination of the apology of the Christian religion and further tightening this scope to the first oldest and classical apologia of Christianity, a new type of apologetics with its own material object is being created. 
The material object of the new type of apologetics is the apologia that Jesus Himself carried out in relation to His own functional and genetic claims, together with their justification, i.e. motivation, both in a personalistic and a dynamic manner. This material object of apologetics, which is the apologia of Jesus himself, has an eminently historical character and, as a result, opens a broad discussion on the sources with a group of biblical scholars who are engaged in the study of the sources of the life and work of Jesus. At the moment, there are four schools of biblical rationalism, each one providing a different solution to the two-stage apology of Jesus.

According to the historical-critical school (Harnack, Goguel, Cullmann), it should be said that Jesus reached his messianic consciousness by way of its gradual development (the prophet, the Son of God, the Messiah). The above-mentioned line of psychological development proposed by this school, guided by the $\mathrm{M}$ and Q pre-synoptic sources, is not supported by these sources and is therefore one-sided. Instead of developing this consciousness, Jesus' pedagogical development can and must be accepted, i.e. Jesus gradually and slowly reveals to the unprepared environment his claims, which from the very beginning were messianic. Among the supporters of the historical-critical school there is a change of views in the direction that brings them closer to the traditional position. According to Cullmann who is a modern representative of this school, it must be said that Jesus made claims of the prophet, and considered himself a suffering servant of YHWH. In addition, Jesus used the phrase "the Son of Man" instead of the title of "the Messiah." Cullmann believes that some of these titles were within the reach of the consciousness of Jesus without mentioning their evolution.

According to the biblical school of eschatology, Jesus was the Messiah only by vocation (in spe), i.e. He considered Himself to be destined to hold the dignity of a Messianic. Jesus hid His Messianic destiny among His disciples, and only Judas revealed Jesus' Messianic mystery. The position of this school is a classic example of the use of an exaggerated methodological postulate to get to know historical personalities in sources only and exclusively in the light of the historical environment, which in this case shared the eschatological ideology. This postulate, however, removes the difference between the ideology of the individual and the ideology of the environment and consequently the question of the influence of one ideology on another is distorted.

While the above-mentioned schools recognized in the two-throw apologia of historical Jesus only the first projection, and partially that is his declaratory consciousness, the other two schools completely reject both projections, in the apologia of the historical Jesus. 
The historical-religious school (Bousset, Conzelmann), following the $\mathrm{M}$ and $\mathrm{Q}$ sources in which it sees numerous editorially related fragments concerning the activity of Jesus, present a thesis that is even contradictory to the previous school. The school maintains that Jesus of Nazareth was not the Messiah and did not make any claims to be the Messiah; only the community, on the basis of their faith or the Easter experience believed in the Messianism of Jesus. The sources $\mathrm{M}$ and $\mathrm{Q}$ are not historical papers but only documents of the faith of the disciples in Jesus, and the authentic tradition of Jesus is not Messianic. Suffice to say, however, that this school introduces an eminently psychological or subjective interpretation into the sources in order to fill the gaps in the sources and does not distinguish between the faith of the disciples in Jesus and their testimony or Jesus' testimony.

Finally, according to the Historical-Morphological School, the two-stage apologia of Jesus is still undergoing further changes due to a completely different approach to the question of sources. According to this direction, the gospels are collective works that consist of small and separate literary units. The Evangelists, their authors, were not just collectors of ready-made material from the oral tradition but had an objective in the composition of the material. Their actual work was limited to the editorial connection of both individual and group fragments without disturbing their original form or only barely. To the positive achievements of this school we should refer the new approach to the synoptic gospels as kerygmatic works, i.e. as works which transmit apostolic oral catechesis in writing. Referring to the question of the apology of Jesus himself contained in the gospels, this direction maintains that we know nothing about the apology of the historical Jesus, we know only at most the apology of the kerygmatic Jesus, either as preaching the kerygma of the kingdom of God or as preaching the kerygma of the community.

The last two schools look with different eyes at the gospel as sources to write the life and work of Jesus. According to the historical-religious school, these sources are so deeply rooted in a layer of faith that no historian can get beyond the layer of faith. This agnosticism of the historical-religious school is maintained, albeit in a slightly different editorial office, by the historical-morphological school when, due to the kerygmatic character of the gospel, it claims that beyond the threshold of the kerygmatic Jesus it is impossible on a literary level to get to know the historical Jesus and his own apology. Thus, in light of the last historical-morphological direction, in the present research on gospels the problem of the material object in modern apologetics also needed to change, namely how one can move from the plane of kerygmatic Jesus to the plane of the historical Jesus and his own apologia. Without getting involved in the 
solution of this problem, which exceeds the framework of the discussed topic, it is still appropriate to mention the further implied integration of the material object in apologetics. The apologia of the historical Jesus was not limited to his individual person, but also included his person in the social sense. Such a total structure of a material object in modern apologetics as opposed to its integral structure, based on the ratio of the implications of various parts of this object, is the most far-reaching logical cohesiveness of this object.

In previous apologetic works, the material object contained two issues that had been present there, associatively or externally connected, under the characteristic name: demontratio Christiana and demonstratio catholica.

The combination of one part with the other was only causal in the sense that the Jesus mentioned in the first part was regarded as the creator and founder of the Church, which is discussed in the second part of the material object in apologetics, the so-called demonstratio catholica. However, biblical studies of recent times have shown that there must be an implicit correlate between the Messiah and his communion or between Christ and his Church; this is because already in the very teaching of Jesus the Messiah appears together (in the sense of correlated implications) with the idea of God's substitutionary dominion over his people, while in the letters of St. Paul the correlated implications of Christ, the Church are increasingly more clearly marked in the anthropological symbol of the Church $\mathrm{xxxx}$ and in the sacramental symbol $\mathrm{xxxx}$ and in the famous thesis of St. Paul The Church. The Church is the fullness of Christ xxxxx (Eph 1:22; 3:19; 4:13). Modern apologetics sees its material object in a total sense, i.e. its material object is Christus totus, i.e. the whole of Christ including its Church. This kind of total approach to a material object in modern apologetics in accordance with historical biblical sources implies the need for the last integration of a material object in apologetics, which, as we have pointed out above, consists in considering the total Christ as motivating one's claim to be an absolute religious value, that is, the Sanctum. Built by Jesus in this way, the full apologia of himself, which is the material object of total apologetics, is twofold. In the first, Jesus Christ makes His absolute functional and genetic claims, and in the second, He motivates them in a personalistic and dynamic manner, especially by the miracle of His Resurrection.

Such a total structure of a material object in modern apologetics as opposed to its integral structure is based on an implied integration of various parts of this object. The object is the most far-reaching logical cohesiveness of the object.

It seems that in this way, I made an attempt to integrate a three-stage material object in the apologetics of the previous one: 1) there is no need for the 
theoretical inclusion of the parts about religion due to the proper development of religious studies at the present time; 2) the two remaining parts (about Christ and about the Church) are merged on the basis of the existing correlation implication between them; 3 ) there is a content implication between the declaration of Jesus and his motivation in the two-view apology of Jesus himself.

What remains to be discussed is an attempt at implied integration in the formal object of modern apologetics.

2. The implicative integration of a formal subject in modern apologetics. When it comes to the formal object, that is, the point of view from which apologetics captures the oldest, classical apologia of Jesus himself, it will be the axiological approach, that is, the critical value of this apologia. Depending on the three different types of modern apologetics (intellectual, voluntary and total), their axiological approach will also differ.

a) Intellectual apologetics, represented by the Dominican theologian Gardeil, assumes that credibility is an indispensable condition of dogmatic faith or Catholic dogma and a formal object of apologetics. Such an intellectual solution of the formal object in apologetics, although it gave uniformity to the apologetic material, cannot suffice nowadays.

This is because credibility is an eminently cognitive element, which does not exhaust comprehensively the construction of religious reality, and which it intends to lead others to.

b) In order to bring man's age closer to religion, voluntary apologetics carries out the analysis of its psychological side (reason, will, feelings) and even shares the Cantanes' assumption that nothing can enter into man if he does not find an equivalent in himself. Based on an analysis of the votive part of a man, Blondel came to the conclusion that the principle of intellectual and moral autonomy in a man leads to the adoption of his heteronomy or dependence on a higher and transcendent reality. However, the attempt at voluntarist apologetics called a new one, i.e. to bring man closer to the Christian religion as a value worthy of desire, does not achieve its goal. Then the apologist will state that the Christian religion is an optional religion, and not a necessary religion to be accepted, and will therefore deviate from the historical reality of that religion. Finally, taking into account the Cantanesian assumption, voluntary apologetics is not able to protect itself against naturalism, i.e. it is not able to draw a demarcation line between natural order and supernatural order.

c) The exuberant intellectualism and exaggerated voluntarism, to which the previous two approaches to the formal object (goal) of apologetics lead, gave rise to the need for another solution to the problem that would on the one hand avoid the above-mentioned exaggeration and on the other took into account the 
unity and the whole of the psychological subject. The beginnings of such a formal object in modern apologetics date back to the second half of the $19^{\text {th }}$ century. He presented it in the form of a harmony between so-called internal fact, that is, the awareness of a certain spiritual vacuum, one's own inadequacy, hope for help from above, and the external fact, that is, the living word of the Church's teaching authority as a postulate of internal fact. At the end of the $19^{\text {th }}$ century, Blondel, the creator of the philosophy of insufficiency (integral realism), set about building modern apologetics based on the method of immanence based on Kant's contemporary and dominant philosophy. The method of immanence in Blondel's case ultimately boils down to a rather characteristic observation, namely that we feel in ourselves, in the religious and moral field, the need for a certain, unspecified surplus. Here, he notices Blondel's established harmony a priori, from which a certain whole (totum, integrity, plenary) is created, where the supernatural element, despite its immanence in a man, retains its heteronomical character. The vital psychological-metaphysical synthesis, which in Blondel's case is a formal object of apologetics, does not differ significantly from the vital psychological-historical synthesis in Dechamps' case. In these two approaches, there is neither a function for individual psychological factors in this synthesis nor any characteristic point of view when it is performed in apologetics. These deficiencies are to eliminated by Poulpiquet's work of 1912, which sets the formal subject of apologetics as the preparation not only of the intellect, but also of the will, as the decisive factor, because it determines the genesis of faith. In this respect, Poulpiquet considers it necessary, on the one hand, to purge the will from internal opposition to faith and, on the other hand, to point out the harmony between the content of the Christian religion and the deepest aspirations of a man seeking a rational response to the protological and eschatological issues of concern to his consciousness. From here comes the desire for religious reality. In this way, Poulpiquet creates the so-called integral apologetics that examines the Christian religion in the light of human needs and the various aspirations of human consciousness. This type of apologetics is based on a broader than intellectual basis because it takes into account the moral values of the Christian religion. The solution given by Poulpiquet, although it further raises the question of the organization of scientific apologetics, is not yet sufficient, since it does not lead to the historical reality of the Christian religion as an absolute necessity but presents it as an optional religion.

It would not be an exaggeration if we understood intellectual and voluntary apologetics as part of a whole called total apologetics. The values of truth and goodness, which were the formal object of intellectual and voluntary apologetics, are further consolidated here in a higher synthesis called sanctum, as 
an absolute religious value, and form the formal object of total apologetics. According to the empirical approach, total apologetics is a critical and systematic cognition, from the axiological point of view, of the self-defense of Jesus Christ as the highest religious value (Sanctum). In other words, total apologetics, by critically analyzing the apology of Jesus himself, comes to the conclusion that Christ totus is a Sanctum or absolute religious value (truth), in relation to which the whole psychological reality of a man (homo totus) is involved in taking a specific position.

Below is presented a set of critically stated sentences, which includes an attempt to solve one of the main issues in modern apologetics, i.e. its internal organization into independent science.

The above approach to the structure of apologetics (Christus totus - homo totus) was discussed in my monographic works on the subject of total apologetics (1937) and on its methods (1938). Based on these works I conducted lectures on apologetics and discussions at apologetic seminars, which I resumed after the outbreak of the war with an increasing interest among listeners, and appearing relevant publications on the new rebuilding of traditional apologetics further deepened these interests. Discussions, interests, lectures, publications took on a more organized character after the establishment of the team chair of apologetics in 1956 with its religious and apologetic departments at the Faculty of Theology of the Academy of Catholic Theology. Since then, the theory of total apologetics has been discussed favorably at apologetic congresses and at numerous theological universities in Poland.

To conclude, I would like to extend my gratitude to all my colleagues and supporters who actively participated in the scientific discussions of the apologetic seminary and thus contributed to the clarification of many thoughts in total apologetics. On this occasion, I openly express my sincere desire for a theory of total apologetics, which has already developed into the Warsaw apologetic school with its reach in numerous theological universities, to soon transform into an apologetic scientific trend paving the way for new deeper solutions. 